\title{
AID FOR ITALIAN ART AND LIBRARIES (continued)
}

Make your cheque payable to the Art Gallery and mark it "Save Italian Art Fund". In the United States the organizing centre is the Committee to Rescue Italian Art, Incorporated, P.0. Box 1414, Providence, Rhode Island 02901.

\section{PRE-1700 HOLDINGS IN THE ROBERT ADDISON COLLECTION, NIAGARA-ON-THE-LAKE}

$$
\text { by }
$$

\section{George McKnight}

A most important private collection of Renaissance and eighteenth century books in Ontario remained in relative obscurity until two years ago when Professor William J. Cameron of the Department of English, McMaster University, began a short-title catalogue of the library willed in perpetuity by Robert Addison to St. Mark's Anglican Church, Niagara-onthe-Lake. In the year since I joined him, the catalogue has been completed and is now available at the Rare Books' Room, Mills Memorial Library, McMaster University. A more complete study tracing the origins of the collection, and providing a guide to the eighteenth century books will be found in Dr. Cameron's report on eighteenth century library holdings in Canada, New Zealand, and Australia delivered at the Nichol Smith Seminar in Canberra in the summer of 1966 and to be published in the proceedings.

The collection was begun by Thomas Topping in the late seventeenth century, and was expanded by William Beale and Richard Atkinson while housed at Whittlesey, near Cambridge, from 1704 until 1772. The library then passed into the hands of Robert Addison, the first Anglican missionary on the Niagara Frontier, who brought the collection to North America in 1792. Significantly, all four were Anglican ministers which gave the collection a solid basis in Anglican theology while allowing for varied personal interest. The Addison library, then, was compiled mainly in the eighteenth century and is a far-ranging if somewhat limited survey of the various religious controversies, and a unique single collection of the books most likely to be read by an Anglican minister of that period. In this brief article on the books printed before 1700, I would like to indicate the general outlines of the collection, and note the particular strengths.

The Addison collection contains 1127 titles (totalling 1300 volumes), with 349 titles (or 352 volumes) before 1700. The pre-1700 material includes 264 volumes in English, 82 in Latin, 4 in Greek, and 2 in French. The great majority were printed after 1660 with 167 works dealing generally with theology and related areas of philosophy and moral instruction. Works on the government, duties, and affairs of the Church include a number by Thomas Bilson, Gilbert Burnet, William Sherlock, Henry Spelman, and Edward Stillingfleet. There are also a number of books dealing with Biblical 
explication and commentary by John Edwards, Bishop Fell, Joseph Hall, Richard Kidder, and Henry More. Or again, there are several moral essays and Anglican doctrines presented by Richard Hooker, William Lowth, Richard Lucas, Pierre Nicole, and Seth Ward. The volumes connected with various controversies include Edward Gee, Jeremy Taylor, and Thomas Tenison against Popery; John Edwards, Jonathan Edwards, and Wiliiam Sherlock against Socinianism; Richard Bentley against atheism; John Wilkins on natural religion; and Robert Burscough and Henry Hammond on Schism. There are 12 books which could be generally classed as ecclosiastical histories, both factual and doctrinal. These include the works of John Smith, Roger Twisden, and William Wake on the Church of England; Gilbert Burnet and Henry Warton on the Reformation; John Spotswood on the Church of Scotland; Thomas Deane on Martin Luther; Peter Heylyn on the Presbyterians; Edward Stillingfleet on the Protestant religion; Paolo Sarpi on the Council of Trent; and, of course, Thomas Fuller, The ChurchHistory of Britain, 1655. There are also approximately 250 sermons in the 26 volumes dated from Joseph $\mathrm{Hall}$ in 1637 to William Stephens in 1700. This includes collections by Ralph Brownrig, John Edwards, John Cockburn, Thomas Sprat, Edward Stillingfleet, and Jeremy Taylor, with individual sermons by Ralph Cudworth, Robert Grove, Symon Patrick, and John lillotson. The individual strengths of the theology collection include Richard Bentley, John Edwards, and Edward Stillingfleet.

The secular works in English include 29 volumes dealing with various aspects of history, 12 volumes of literature, 9 volumes of memoirs and biography, and 4 volumes for educational purposes. Those volumes related to English history include works on the law, the monarchy, and civil liberty by Edward Coke, John Cowe, Sir William Dugdale, Edward Hyde, John Milton, John Nalson, Francis Osborn, and Robert Sheringham. The volumes related to Italy include the writings of Machiavelli, and Jean Gailhard's study of the republics. There are also three significant works on the Turks by Richard Knolles, Francis Osborn, and Paul Rycaut, and René Aubert de Vertot's history of the revolution in Sweden. There are few works of literature in the collection prior to 1700 , and those consist mainly of translations of Montaigne and Virgil, the poems of John Oldham, and the essays of Francis Bacon. Finally, the most prominent biographers include Gilbert Burnet, William Cave, Gerard Langbaine, Jeremy Taylor, and Izaak Walton.

The 88 foreign language books include 22 printed in London, 8 in Cambridge, and 6 in Oxford. The remaining 52 volumes which were printed on the continent include 19 from Amsterdam, 7 from Leyden, 5 from Lyons and Cologne, and single volumes from different cities including Frankfurt, Ober-Ursel, and Genoa. The majority of Latin volumes published in England were printed after 1660 and include editions of Cato (1695), Cicero (1681), Juvenal and Persius (1686), Lucretius (1686), and Quintilian (1692). The more contemporary writers include Francis Bacon (1617), Robert Boyle (1665), Hugo Grotius (1700), Robert Grove (1682), John Milton (1676), Matthew Poole (1669), and Izaak Wake (1635). The earliest books printed on the continent date from, Ammianus Marcellinus (1500), George Cassander (1512), Quintilian (1518), Aristotle (1534), Jeronimo Osorio de Fonseca (1576), and Lorenzo Valla (1548). Other books printed on the continent are either ediiions of the classics such as Cicero (1691), Juvenal (1648), Livy (1678), Petronius (1619), 
Plj.ny (1640), Terence (1661), Theophrastus (1638), and Virgil (1613), or the works of modern writers including Johann Henrich Alsted (1624), Jean Bodin (1601), Erasmus (1612), Hugo Grotius (1648), Jason à Pratis (1657), Johann Henrich Ursin (1661), and Hieron Zanchius (1601), and finally a French translation of Cervantes (1692). 